\title{
The Construction of Scientific Knowledge at an Early Age: Two Crucial Factors
}

\author{
Leonidas Anastasiou', Nick Kostaras ${ }^{1}$, Elisabeth Kyritsis' ${ }^{1}$, Athanasia Kostaras ${ }^{2}$ \\ ${ }^{1}$ Department of Education, University of the Aegean, Mytilene, Greece \\ ${ }^{2}$ Aristotle University, Mytilene, Greece \\ Email: anastaleo@yahoo.gr
}

Received 6 February 2015; accepted 24 February 2015; published 28 February 2015

Copyright (C) 2015 by authors and Scientific Research Publishing Inc.

This work is licensed under the Creative Commons Attribution International License (CC BY). http://creativecommons.org/licenses/by/4.0/

(c) (i) Open Access

\section{Abstract}

This article presents and justifies a proposal for the priority of two activities in the early childhood curriculum, namely, those of "storytelling" and the "movement of objects". Given, on the one hand, the growing interest in science activities for very young children, and the notion of "developmental appropriateness" on the other, the concern about early experiences in physical science is both pressing and legitimate. In the light of such concern, the idea that children should simply participate in interesting activities or in activities that in general enrich their experiential background, needs to be reconsidered. Given that the construction of scientific knowledge involves the construction of relationships among concepts and ideas, and presupposes curiosity and affective imagination, science stories with a science content that captures the imagination of the child, and activities involving the movement of objects appear to be more pedagogically appropriate than other activities. Therefore they should be given priority in the curriculum.

\section{Keywords}

Scientific Knowledge, Young Children, Early Childhood Education, Logico-Mathematical Thinking, Narrative Thinking, Movement of Objects, Imagination, Storytelling, Science Stories

\section{Introduction}

Over the last two decades there has been a growing interest in early childhood science education (e.g., Chaille \& Britain, 2003; Eshach \& Fried, 2005; Fleer, 2009; Fleer \& Pramling, 2014; Gerde, Schachter, \& Wasik, 2013; Trundle \& Sackes, 2015). The reason behind this interest is that early experiences in the sciences can help develop in young children attitudes toward science and learning. On the other hand, such experiences help children develop science process skills, which, in turn, contribute to children's cognitive and conceptual development 
(Hadzigeorgiou, 2001, 2002; Trundle \& Sackes, 2015), and hence to better understanding of science in the later years of schooling (Eschach \& Fried, 2005).

It is worth noting that early experiences can provide stimulation and therefore "windows of opportunity" to children during their critical period of development. There is evidence that environmental effects on intellectual development are more pronounced during children's first years in life (Sternberg \& Berg, 1993; see also Hadzigeorgiou, 2002, 2015), and that a cognitive ability or skill may not develop in its full potential (or not develop at all) due to either the lack or the nature of provided stimuli (Bornstein, 1989; Epstein, 1978; Gardner, 1985).

However, a question is raised about the kind of experiences that young children will engage in. The message that a science educator had sent to the educational community is a case in point: "determining what is appropriate physics for first graders is not trivial” (Hammer, 1999: p. 799). Indeed, given the growing interest in science activities for young children, even those in preschool education (e.g., Chaille \& Britain, 2003; Fleer, 2009, 2013; Hong \& Diamond, 2012; Kamii \& DeVries, 1993; Kokoski \& Downing-Leffler, 1995; Landry \& Foreman, 1999; Leuchter, Saalbach, \& Hardy, 2014; Peacock, Smith, \& Kirkby, 1994; Waite-Stupiansky, 1997) the concern about what constitutes an appropriate physical science activity for a young child is a realistic one and should be seriously considered.

Given that the value of a science activity in the context of preschool and early childhood education in general is to be assessed in terms of its "developmental appropriateness" (Bredekamp \& Copple, 1997), that is, in terms of providing children with opportunities for both development and learning, some criteria for the selection of the science activities are imperative. In fact, the vast variety of activities that appear in international bibliography (e.g., Atkinson\& Fleer, 1995; Brown , 1981; Browne, 1991; Harlan, 1988; Holt, 1993; Marxen, 1995; Peacock, Smith, \& Kirkby, 1994; Richards, Collins, \& Kincaid, 1987; Sprung, 1996; Taylor, 1993; Trojack, 1979) necessitate the proposal of a theoretical framework for early childhood science education.

Although the action of the child is considered the single most important factor in the learning process (e.g., Maxwell, 1995; Landry \& Foreman, 1999; Nutbrown, 1994; Waite-Stupiansky, 1997) certain ideas need to be reconsidered. For although children can make empirical generalizations through their own actions, it is debatable whether these actions are followed by understanding. For example, children can describe that a magnet attracts certain objects, that water freezes and ice melts, and that their hands get warm if rubbed together. These are descriptions, however, which do not imply necessarily an understanding (Kamii \& DeVries, 1993; Hadzigeorgiou, 2015). Unless children can put their ideas into relationship, all those descriptions will be isolated information. By the same token, children can perform an activity that is quite attractive and feel the same wonder and amazement that they feel when in a circus. Certainly, these empirical generalizations will not be forgotten, since they are the result of children's own actions. However, the important question to be asked is this: do these activities provide children with opportunities for development?

Given that the notion of relationship is central in all perspectives on intellectual development (Sternberg \& Berg, 1993), children should be given opportunities for the construction of relationships. It is these relationships that will form the foundation upon which the development of scientific concepts will take place at a later stage. Although the process of concept development is not fully understood, the view that this process involves the construction of relationships is shared among cognitive scientists, philosophers and science educators (e.g., Ausubel, Novak, \& Hanesian, 1978; Basseches, 1980; Bruner, 1963; Case, 1985; Duschl, 1990; Entwistle, 1987; Hadzigeorgiou, 1997; Hirst, 1974; Novak \& Gowin, 1984; Prawat, 1989; Reif \& Larkin. 1991; Resnick, 1983; Scheffler, 1991). Vygotsky (1986), in fact, had made this point quite explicit: “...the very notion of a scientific concept implies a certain position in relation to other concepts, i.e., a place within a system of concepts” (p. 93). However, children should be also given opportunities to develop their imagination, since the role of the latter in the development of scientific knowledge is well recognized (Shepard, 1988; Taylor, 1967). The curriculum framework therefore for an early childhood science education could be based upon the following ideas:

- There are two different but complementary modes of thinking: the paradigmatic and the narrative (Bruner, 1986).

- The paradigmatic mode involves logico-mathematical thinking and is identified with such processes as generation and testing of hypotheses, and construction of relationships resulting from the connection and comparison of objects and situations (Copple, Sigel, \& Saunders, 1984; Kamii \& DeVries, 1993; Piaget, 1976, 1977).

- The narrative mode involves divergent thinking and is identified with story-telling (Bruner, 1986; Egan, 
2005; Martin \& Brouwer, 1991).

- The reliance on the paradigmatic mode, that is on logico-mathematical thinking (e.g., Copple, Siegel \& Saunders, 1984; Kamii \& DeVries, 1993), is not only inadequate but also inappropriate in the context of early childhood education (Egan, 1997, 1999a).

- The narrative mode provides opportunities for capturing children's affective imagination (see Fleer, 2013; Hadzigeorgiou, 2001), which is an indispensable element in the process of concept development (Hadzigeorgiou, 2014; Shepard, 1988; Stinner, 1995; Stinner \& Williams, 1993).

- In the case of young children the use of the narrative mode leads to conceptual development and the construction of meaning through a mediation process between two binary opposite concepts that form the structure of the plot (Egan, 1988, 1999b, 2005).

The question, of course, is which activities are more appropriate for very young children, taking into account the two modes of cognitive functioning. The discussion that follows is an attempt to answer this question, and, at the same time, justify their priority in the curriculum. The discussion focuses on two curricular activities/approaches to teaching science to very young children (i.e., ages 4 - 8): 1) the movement of objects (targeting the development of the paradigmatic mode of thought) and 2) story-telling (targeting the development of the narrative mode).

\section{The Role of the Movement of the Objects}

Although there is some overlapping among all science activities, a distinction should be made between science activities that contribute to children's cognitive development and activities that enrich children's experiential background (Hadzigeorgiou, 1998, 2015). Certainly a rich experiential repertoire is not only important but also necessary in the process of concept development. Prior experiences, according to Howe (1996), give children the possibility to go from the abstract concepts that they will be learning later in school to their concrete experiences and vice versa. Movement, as she points out, is necessary in both directions. However, it is one thing for a child to have the experience, and know (but not understand) that magnets attract certain objects, that the beam of a flashlight is straight or that water can be better absorbed by certain materials, and another thing to be able to get feedback from the reaction to his or her own action, and be able to organize those reactions in schemata and sub-schemata. It is this organization and reorganization that helps children construct relationships among a number of factors and therefore understand what is going on in certain situations. A child, for example, playing with objects of various sizes will construct a relationship between size and weight. However, the child will probably construct a relationship between weight and type of material provided that he or she has the opportunity to lift objects consisting of different kinds of material. A child also, trying to make a ball bounce as high as possible, will construct relationships among the force he or she is applying, the direction of the force, and probably the kind of the material of the ball.

Given the limitations of children's cognitive abilities (e.g., egocentricism, animism, transductive thinking) (Ginsburg \& Opper, 1969) as well as the findings of research on children's ideas (Driver, Guesne, \& Tiberghien, 1985; Gilbert, Osborne, \& Fensham, 1982; Trundle \& Sackes, 2015), it would be unrealistic to expect young children to understand physical phenomena. Kamii and DeVries (1993), in fact, are critical of the idea that science education activities should aim at helping children understand apparently simple everyday phenomena (e.g., the formation of rain, electricity). These phenomena are too ambitious, particularly for preschool children.

So which activities are more appropriate for young children? Kamii and DeVries $(1977,1993)$, in answering this question, have made an important contribution to our understanding of the various science activities and their effect on children's development. Following the parallelism "between the progress made in the logical and rational organization of knowledge and the corresponding formative psychological processes” (Piaget, 1970: p. 13), Kamii and DeVries (1993) consider the history of science the best guide as to what is more appropriate for preschool children.

In primitive times, people were interested in cooking, plants, animals, and art. Just as these people structured their observations, young children learn about the properties of objects and living organisms and their interactions by acting on them and observing the regularity of their reaction. (Kamii \& DeVries, 1993: p.

11)

In selecting therefore activities one should consider the activities of primitive people. The action on the part of the child appears to be the starting point in the selection process. Depending upon the relative importance of 
“action” and “observation”, Kamii and DeVries (1977) distinguished between two broad categories of activities. The first category consists of activities in which the action on the part of the child is of primary importance, while the observation of the result of that action is of secondary importance (e.g., throwing a ball, pushing a box on the floor). The second category consists of activities in which the observation is of primary importance, while the action is of secondary importance (e.g., playing with a magnet or a mirror). Apparently, not all science activities can fall into these two categories, so Kamii and DeVries (1977) created another category to include other activities like dissolving different substances into the water, watching objects floating and sinking in the water and so forth. Apparently, from a constructivist point of view the best activities are those involving children's own action.

The above categorization, however, might be a little confusing to some since action appears to be always involved and in fact be of primary importance in the case of most activities (e.g., floating and sinking, shadow playing, mixing materials). A more careful look, however, can reveal that while in some activities the reaction is due exclusively to the child's own action (e.g., rolling a can down an incline, pulling a box, balancing a structure), in some other activities the reaction is due to the properties of the materials used and factors beyond the child's control (e.g., mixing, cooking, ice melting, crystall making). It is probably for this reason that Kamii and DeVries (1993) have proposed the following three categories of activities: The first category includes activities involving the movement of objects (e.g., hitting a ball, swinging a pendulum, rolling a can) while the second category includes activities involving the change in objects (e.g., playing with water and ice, mixing different materials, growing seeds). The third category includes all the activities that fall between these two categories, (e.g., playing with the magnet, with floating and sinking objects, producing echoes). In the first category, the role of action is primary since the child has first to act in order to observe the reaction of the object. In the second category, the role of observation becomes primary and that of action secondary because "the reaction of the object is neither direct nor immediate; that is, the outcome is due not to the child's action as such, but to the properties of the objects" (Kamii \& DeVries, 1993: p. 6).

The best activities in the context of early childhood education appear to be those involving the movement of various objects (Chaille \& Britain, 1997; Kamii \& DeVries, 1993). Kamii and DeVries (1993) believe that following criteria should be used for the selection of good activities:

1) the child must be able to produce the movement by his own action,

2) the child must be able to vary his action,

3) the reaction to this action must be observable, and

4) the reaction must be immediate.

Copple, Sigel and Saunders (1984), however, consider change an important criterion for selecting appropriate activities. The criteria they have proposed are the following:

1) the activity should provide opportunities for the child's own action,

2) the activity should involve discrepancies,

3) the activity should involve transformations and rapid changes that can be observed and

4) the number of factors involved in the change should be small.

The ideas of transformation and contradiction are central in Piaget's $(1976,1977)$ latest work, and apparently they have been incorporated in these criteria.

But why are activities involving the movement of objects more appropriate for very young children? For it could be certainly argued that it is quite difficult to maintain a tight division between, for example, the activity of floating and sinking and that of rolling a ball on an incline. For both activities involve action (the child places the ball on the incline but also in the water), variation of the action (the child can release the ball from different points on the incline but also release it from various heights above a sink, place it on the surface of the water or even underneath it) and immediate observation (the child observes the ball rolling but also the ball sinking or floating). Yet activities involving the movement of objects are considered more appropriate for a number of different reasons.

First, they offer opportunities for purposeful action. There is not just manipulation of an object. The child is guided by what he or she wants to achieve (e.g., hitting a box, balancing a structure, making a ball roll as far away as possible) and of course by the reactions of the object. These reactions provide feedback that allow the child to modify his or her action.

Second, activities involving the movement of objects satisfiy the criterion of variation of action to a greater extent. It is this variation that enables a child to compare and contrast the objects' reactions (e.g., the greater the 
force applied on the ball the farther it moves, the higher from the ground a superball is released the higher it bounces off). These comparisons, as was previously pointed out, can help the child to organize the objects' reactions in schemata and subschemata. By contrast, any object will either float or sink, regardless of the variation of the child's action.

Third, activities involving the movement of objects offer opportunities for the construction of relationships among a number of various factors (e.g., time, distance, speed, force, type of material). A ball rolling down a ramp and hitting a box placed on the table or the floor and at the foot of the ramp, will lead the child to construct relationships between the weight of the ball and its velocity (the heavier the ball the faster it goes), between the weight of the ball and the distance the box is displaced (the heavier the ball the farther the box goes), between the height from the table or the ground the ball is released and the distance the box moves, etc. This activity, and of course many of its variations, help children construct relationships that will form the foundation for the development of the concept of mechanical energy. By contrast, in the floating and sinking activity the factors that the child can relate are only the type of objects with their behavior (e.g., wooden things float, stones or heavy things sink). In addition, as children anticipate the movement of objects, they are also coordinating spatio-temporal relationships. In other words, movement activities provide children with more opportunities for operative (logico-mathematical) thinking.

Fourth, activities involving the movement of objects offer opportunities for transformational thinking since children can watch the changes in position of the moving objects (Marxen, 1995). In the case, for example, of a ball rolling down an incline this quite evident. In contrast, in shadow playing there is no transformational thinking (see Woodard \& Davitt, 1987), despite the fact that this particular activity satisfies all four criteria given in connection with the movement of objects (e.g., the child can produce the movement of his body, can vary his or her position relative to the position of the sun or the position of the arms and legs relative to his or her body, and then watch immediately the different outlines of the shadows produced).

Apparently activities involving changes in objects do not satisfy the criteria of appropriate activities, according to Kamii and DeVries (1993) (except in the case of changing the shape of an object by applying a force). Whether a child is mixing various materials or dissolving a number of them in water, his or her action does not vary as in the case of the movement of objects. Moreover, the change that is produced is not due to the child's action but to factors inherent in the materials themselves. Even in the case of a child placing a plastic cup filled with water in the freezer, the change of water into ice is not due to the child's own action (i.e., putting the cup into the freezer), but to the chemical bonding between the water molecules.

A last word concerning the activity of "the movement of objects" should be said about the child's own body, whose movement satisfies all criteria of activities according to Kammi and DeVries (1993). In other words, the child's own body can be considered "an object", which can produce (exert), and be acted upon by, force(s). Given the evidence that sensorimotor activities can indeed facilitate the construction of knowledge in the early years (see Hadzigeorgiou, Anastasiou, Prevezanou, \& Konsolas, 2009; see also Hadzigeorgiou \& Savage, 2001), their priority in early education curriculum can be justified.

\section{The Role of Narrative}

It appears that the role of stories in early childhood education has to be rediscovered, since a closer and more careful look at children's mental life and capacities has shown the great importance of their orality (Bruner, 1986; Egan, 1994, 1997, 1999a, 1999b, 2005). The idea that information presented through the plot of a story is better understood and remembered than when presented in a logical or conceptual sequence is well documented (Bruner, 1986, 1992). The reason why people learn and remember more through a story is that the latter helps create in their mind a context. It is well known that context plays a major role in human understanding (Carey, 1986; Prawat, 1989). A story, as Egan (1986) argues, appears to be more appropriate than other means of communication in describing ideas about the world. According also to Martin and Brouwer (1991),

A story with just a few well chosen words, can draw in the reader or listener and create a world of shared experience. The story can at times communicate in few words that which a dense, technical analysis might require many lines to accomplish. (p. 708)

But what about scientific concepts and ideas? There is a difference between history or literature and science, although, it might be argued that, even in the case of history, children should learn the truth about the world from reliable sources, not through stories. Objectivity appears to fly in the face of narratives since the latter in- 
volve always an element of personal interpretation.

Yet despite this element of interpretation, the link between science and myth leads one to reconsider one's notion of truth. Although it is beyond the scope of this article to analyze and discuss the ideas of objectivity and truth, it is worth pointing out that

Today's science is built upon yesterday's science, and yesterday's science upon the science of the day before. And the oldest scientific theories are built on pre-scientific myths. (Popper, 1972: p. 346)

The scientific theory that is used to explain, for example, the connection between volcanoes, earthquakes and mountains is rooted in the myth of the Titans. It is well known from Greek mythology that the ancient greeks were aware of a link between those phenomena, and that they created a myth to explain them. This is the myth of the Titans, a tribe of giants, who were imprisoned by Zeus underneath the mountains, and, in their attempt to escape, began to throw big rocks at Zeus. Although the scientific theory of today does not postulate the existence of angry giants who move and throw rocks, the hypothesis that there is movement of techtonic plates is not different from the story of the ancient Greeks. Bruner (1986) makes this point quite explicit: "Many scientific and mathematical hypotheses start their lives as little stories or metaphors" (Bruner, 1986: p. 12). He also argues that a scientific theory and a well-made story "are two forms of an illussion of reality" (p. 52). Egan (1999b) argues that if rationality is considered the natural way of thinking, "then clearly most of humanity most of the time have been involved in massive confusion" (p. 5).

It is no coincidence that over the last two decades the importance of imagination and intuition, and the role of the right hemisphere in general in the process of knowing have been seriously considered (Bruner, 1986; Clocksin, 1995; Egan \& Nadaner, 1988; Egan, Cant, \& Judson, 2014; Eisner, 1985; Levy, 1985). Bruner (1986), in fact, argued that there are two distinctive modes of cognitive functioning, the narrative and the paradigmatic; the former gives rise to story telling, and the latter to logic and science in general. However, although these two modes of thought are irreducible to one another, they are complementary.

These ideas lead one to consider the story-line approach as an excellent way to help children understand certain ideas about science. For young children a story is not just a powerful tool but a pedagogical necessity. As Egan (1979: p. 2) points out, "young children require a story form. They require a beginning that sets up an expectation, a puzzle, a problem, or what writers call a sense of tension”. Topics, according to Egan (1988, 1994, 1997), embedded in a context capturing the imagination of the child, should be presented in such a way that the child perceives the conflict between two binary opposites (e.g., good and evil, big and little, hope and despair, security and fear).

A mediating process between binary opposites appears to facilitate the understanding of a large range of phenomena. For example, through a mediation process between "hot" and "cold" children learn the concept "cool", in the same way that through a mediation between living and dead things children learn the notion of "ghost" (Egan, 1999b). This mediation process between two opposites appears to be central in the process of meaning making (Odgen, 1967). Egan (1988) gives the example of heat that could be presented to children in a story form through a conflict between heat as a destroyer and heat as helper. Apparently, Egan's idea of binary opposites, can be used to introduce children to a large number of scientific ideas. This can be done if stories are built on conflicts between such concepts as light and shadow (darkness), heavy and light, motion and rest, energy as something good and energy as something bad, water that stays still and water that is in constant motion, could be used for the introduction of science concepts to young children.

Egan is a fervent exponent of the idea that instead of thinking of a lesson or unit as a set of instructional objectives to be attained, teachers should think of it as a good story to be told to the children. Egan (1997), in fact, proposes that educational development should proceed in the following four stages: mythic, romantic, philosophical and ironic stage. Children, according to this four-stage model, should begin to learn about the world through the great stories of the world. Whether or not Egan's ideas are challenging, their importance for the early childhood curriculum is quite indisputable, since orality plays a primary role in early childhood. In addition, his ideas necessitate a reconsideration of the capacities of young children, and provide food for thought for those interested in helping children construct a foundation for science concept development.

A feature of young children's mental life that is commonly asserted as an implication of research on their logico-mathematical thinking is that their thought is perception-dominated. If we focus instead on their imaginative lives we see rather an enormously energetic realm of intellectual activity that is conceptiondriven. (Egan, 1999b: p. 9) 
However, what is perhaps equally important is that stories, especially when they violate everyday reality (e.g., through unfamiliar, mysterious, remote and strange objects and situations), can provide children with a sense of wonder (Hadzigeorgiou, 1999, 2001, 2014; Womock, 1989). This sense of wonder can secure the "romantic" engagement with the scientific ideas, which, according to Whitehead (1929), is a necessary step before children can begin to study science in detail at a later stage in their education. If the goal of early childhood science education is to provide opportunities for children to build the foundations for scientific knowledge, then attention should be paid to those characteristics of children's mental life that facilitate this construction process. These characteristics are curiosity/wonder and imagination, and they can both be developed and sustained through exciting stories, in which science concepts and ideas have been embedded.

\section{Final Comments}

Although the growing interest in science activities for young children is welcome, this interest could become manifest in two extreme ways, something that should be avoided. One can spend one's lifetime trying to find effective ways to introduce children to science concepts and ideas, taking, of course, into account both the limitations in children's thinking and their preconceptions about how the world works. Or one can spend one's lifetime designing interesting activities that might appeal to young children. Following the first rationale, one will probably never design a single activity, while following the second rationale one will design too many. Both approaches are extreme and should be avoided.

Certainly, Jerome Bruner's (1966) famous dictum that "any idea or problem or body of knowledge can be presented in a form simple enough so that any particular learner can understand it in a recognizable form” (p. 46) has been a real challenge for any educator genuinely concerned with learning. This dictum is certainly a bold hypothesis. Can we teach the theory of relativity to five or six year old children? Can we help children understand Newton's Third Law and the Second Law of Thermodynamics? Yet Bruner (1963), had remarked in regard to his hypothesis: "No evidence exists to contradict it; considerable evidence is being amassed that supports it” (p. 33).

Today Bruner's hypothesis appears to be more realistic than it was twenty or thirty years ago as findings from cognitive psychology support the Vygotskian view that learning can occur in advance of development. For there is evidence that learning does not depend so much upon the level or stage of cognitive development of the child as upon the representations he or she has about a certain subject or topic, and the strategies he or she uses to process information (Berg, 1993). The guidance that the child receives from adults or more knowledgeable peers also plays a crucial role in the process of learning (Berk \& Winsler, 1995; Bruner, 1985; Fleer, 2009, 2013; Hadzigeorgiou, 2015; Hodson \& Hodson, 1998; Navarra, 1955; Rogoff, 1990).

The important question to be asked, however, is not whether children can be introduced to advanced ideas, but whether, through their participation in science activities, they have the opportunity to develop, and, at the same time, to be helped to construct the foundation upon which the development of science concepts will take place. In regard to the development of children, the activities should provide opportunities for cognitive, emotional, physical and social development. In regard to the foundation of scientific knowledge, the activities should provide opportunities for the construction of relationships between fundamental concepts, and for the development of attitudes and skills.

Although the movement of objects and stories represent a restricted repertoire of activities, they can nonetheless be considered pedagogically more appropriate activities, in the sense that they can help children construct the logico-mathematical framework necessary for concept construction and develop their imagination, which is an important element in this construction process. Moreover, both activities can also be considered from a sociocultural/constructivist perspective, which is based upon the collective-not the individual-nature of learning (see Fleer, 2009, 20013; Fleer \& Pramling, 2014).

Certainly, the construction of relationships can result in knowledge that lacks the coherence of scientific knowledge. The understanding, for example, of a situation involving the collision of two bodies necessitates the construction of relationships among a number of various concepts (e.g., mass, force, velocity, length, time). Even in a relatively simple everyday situation involving the free fall of an object there can be so many relationships constructed by children (e.g., relationships between time and speed, between height and speed, between height and time, between height and force exerted the moment the object hits the ground) that a reorganization is imperative if scientific understanding is the goal. Yet this does not imply that children cannot be helped to organize their thinking by constructing relationships or linkages among concepts that have some coherence (see 
Eschach \& Fried, 2005; Leuchter et al., 2014; Trundle \& Sackes, 2015). It does not follow that children cannot be helped to construct understanding by participating in appropriately designed activities that deliberately engage them in relational thinking. The idea of "construction of understanding” (see Hadzigeorgiou, 2015), which is compatible with both the actional and the relational view of scientific concept (Gilbert \& Watts, 1983), not only points towards the importance of relationships, but also has serious implications for pedagogy: children should be encouraged and helped to put various factors and ideas in relationship.

No mention of course, has been made of the role of science skills like observing, describing, recording, hypothesis testing etc., or the role of values and attitudes. Yet it is quite evident that both story-telling and activities with the movement of objects do help children develop both attitudes and skills. Curiosity, for example, can be developed if children listen to interesting science stories, and skills can be developed through children's participation in activities involving the movement of objects. Moreover, through storytelling and the movement activities emphasis is placed not on sense experience but on children's mental actions.

Although it is true that science involves looking closely at an object (e.g., a worm, a magnet, a mirror) or an event (a pendulum swinging back and forth, a melting piece of ice, a ball rolling down an incline), and that children's thinking process does start with observation (children have first to observe an object or situation before they can describe the object and certainly before they understand what is going on in the situation, which factors are involved in this situation, let alone form hypothseses, investigate and test their ideas), there is the possibility, for children to rely heavily on inductive reasoning. However, the epistemology of empirical inductivism has suffered a strong blow over the last decades (Chalmers, 1982, 1990; Driver, 1994) since it was recognized that many scientific concepts are imaginary constructions rather than the consequence of any direct observation. Ausubel, Novak and Hanesian's (1978) idea that when "young children are discovering principles inductively, they are really attempting to use empirical evidence to confirm their existing preconceptions" (p. 538), is not only an argument against the epistemology of empirical inductivism but also a warning for educators, particularly those in preschool education. Children's egocentric and animistic beliefs undermine the view that they can actually observe and understand physical phenomena.

Given the complementarity of the two modes of cognitive functioning, it is apparent that even the generation of hypotheses is not due exclusively to logico-mathematical thinking. The idea that a hypothesis comes first, as an imaginary construction, and that the data of observation are used to validate the hypothesis (Phenix, 1964; Popper, 1972) does lead one to reconsider the development of scientific skills as the most important element in early childhood science education. For Copple, Sigel and Saunders (1984), the development of these skills in young children is equivalent to the development of their mental capacities. Attention, however, should be paid to the role of observation and sense experience in general. For emphasis on sense experience might have the opposite result, that is, the neglect of both logico-mathematical thinking and imagination (Hadzigeorgiou, 2015). Egan’ (1999a) view, that the neglect of the imagination in the early years can explain failure in science and mathematics later on should be seriously considered.

A closing argument for the priority of activities involving the movement of objects and storytelling, regards the teachers' capacity to implement them. Given the bleak picture of early childhood teachers' confidence to teach science in general (see Fleer, 2009; Gerde et al., 2013), the proposed two approaches seem to help teachers become more confident about physical science teaching in the early years (Hadzigeorgiou, 1998, 2004). Perhaps, this is a kind of teachers' confidence in implementing science activities in early childhood education is.

\section{References}

Atkinson, S., \& Fleer, M. (1995). Science with Reason. London: Hodder and Stoughton.

Ausubel, D., Novak, J., \& Hanesian, H. (1978). Educational Psychology: A Cognitive View. New York: Holt, Rinehart and Winston.

Basseches, M. (1980). Dialectical Schemata. Human Development, 23, 400-421. http://dx.doi.org/10.1159/000272600

Berg, C. (1993). Perspectives for Viewing Intellectual Development throughout Life. In R. Sternberg, \& C. Berg, (Eds.), Intellectual Development. Cambridge: Cambridge University Press.

Berk, L., \& Winsler, A. (1995). Schaffolding Children's Learning: Vygotsky and Early Childhood Education. Washington DC: NAEYC.

Bornstein, M. (1989). Sensitive Periods in Development: Structural Characteristics and Causal Interpretations. Psychological Bulletin, 105, 179-197. http://dx.doi.org/10.1037/0033-2909.105.2.179 
Brown, S. (1981). Bubbles, Rainbows and Worms. Mt Rainier, MD: Gryphon House Inc.

Browne, N. (1991). Science and Technology in the Early Years. Buckingham: Open University Press.

Bruner, J. S. (1963). The Process of Education. Cambridge, MA: Harvard University Press.

Bruner, J. S. (1966). Toward a Theory of Instruction. Cambridge, MA: Harvard University Press.

Bruner, J. S. (1985). Vygotsky: A Historical and Conceptual Perspective. In J. Wertsh (Ed.), Culture, Communication, and Cognition: Vygotskian Perspectives. Cambridge: Cambridge University Press.

Bruner, J. (1986). Actual Minds, Possible Worlds. Cambridge, MA: Harvard University Press.

Bruner, J. (1992). Acts of Meaning. Cambridge, MA: Harvard University Press.

Carey, S. (1986). Cognitive Science and Science Education. American Psychologist, 41, 123-130.

Case, R. (1985). Intellectual Development: A Systematic Reinterpretation. New York: Academic Press.

Chaille, C., \& Britain, L. (2003). The Young Child as Scientist: A Constructivist Approach to Early Science Education (3rd ed.). New York: Harper Colins.

Chalmers, A. (1982). What Is This Thing Called Science? Milton Keynes: Open University.

Chalmers, A. (1990). Science and Its Fabrication. Minneapolis: University of Minnesota Press.

Clocksin, W. (1995). Knowledge Representation and Myth. In J. Conrwell (Ed.), Nature's Imagination: The Frontiers of Scientific Vision. Oxford: Oxford University Press.

Copple, C., Sigel, I. E., \& Saunders, R. (1984). Educating the Young Thinker. New York: D. Van Nostrand Co.

Driver, R., Guesne, E., \& Tiberghien, A. (Eds.) (1985). Children's Ideas in Science. Milton Keynes: Open University Press.

Driver, R. (1994). The Fallacy of Induction in Science Teaching. In R. Levinson (Ed.), Teaching Science. London: Routledge.

Duschl, R. (1990). Restructuring Science Education. New York: Teachers College Press.

Egan, K. (1979). Educational Development. New York: Oxford University Press.

Egan, K. (1986). Teaching as Story Telling. London, Ontario: Althouse Press.

Egan, K. (1988). Primary Understanding. New York: Routledge and Kegan Paul.

Egan, K. (1994). Young Children's Imagination and Learning: Engaging Children’s Emotional Response. Young Children, 49, 27-32.

Egan, K. (1997). The Educated Mind: How the Cognitive Tools Shape Our Understanding. Chicago, IL: University of Chicago Press. http://dx.doi.org/10.7208/chicago/9780226190402.001.0001

Egan, N. (1999a). Children's Minds, Talking Rabbits and Clockwork Oranges. New York: Teachers College Press.

Egan, N. (1999b). Supplement to Teaching as Story Telling. http://www.educ.sfu.ca/people/faculty/kegan/supplement1.html

Egan, K. (2005). An Imaginative Approach to Teaching. San Francisco, CA: Jossey-Bass.

Egan, K., Cant., A., \& Judson, G. (Eds.) (2014) “Wonder-Full Education”: The Centrality of Wonder in Teaching and Learning across the Curriculum. New York and London: Routledge.

Egan, K., \& Nadaner, D. (Eds.) (1988). Imagination and Education. New York: Teachers College Press.

Eisner, E. (1985). Aesthetic Modes of Knowing. In E. Eisner (Ed.), 84th Yearbook of NSEE: Learning and Teaching the Ways of Knowing. Chicago, IL: Chicago University Press.

Entwistle, N. (1987). Understanding Classroom Learning. London: Hodder and Stoughton.

Epstein, H. (1978). Growth Spurts during Brain Development: Implications for Educational Policy and Practice. In J. Chall, \& A. Mirsky (Eds.), Education and the Brain. Chicago, IL: University of Chicago Press.

Fleer, M. (2009). Supporting Scientific Conceptual Consciousness or Learning in a "Roundabout Way" in Play-Based Contexts. International Journal of Science Education, 31, 1065-1089. http://dx.doi.org/10.1080/09500690801953161

Fleer, M. (2013). Affective Imagination in Science Education. Determining the Emotional Nature of Scientific and Technological Learning of Young Children. Research in Science Education, 43, 2085-2106.

http://dx.doi.org/10.1007/s11165-012-9344-8

Fleer, M., \& Pramling, N. (2014). A Cultural-Historical Study of Children Learning Science. Dordrecht and New York: Springer.

Gardner, H. (1985). The Mind's New Science. New York: Basic Books.

Gerde, H., Schachter, E., \& Wasik, B. (2013). Using the Scientific Method to Guide Learning. Early Childhood Education Journal, 41, 315-323. http://dx.doi.org/10.1007/s10643-013-0579-4 
Gilbert, J., Osborne, R., \& Fensham, P. (1982). Children’s Science and Its Consequences for Teaching. Science Education, 66, 623-633. http://dx.doi.org/10.1002/sce.3730660412

Gilbert, J., \& Watts, M. (1983). Concepts, Misconceptions and Alternative Conceptions: Changing Perspectives in Science Education. Studies in Science Education, 10, 61-98. http://dx.doi.org/10.1080/03057268308559905

Ginsburg, H., \& Opper, S. (1969). Piaget's Theory of Intellectual Development. Englewood Cliff, NJ: Prentice Hall.

Hadzigeorgiou, Y. (1997). Relationships, Meaning and the Science Curriculum. Curriculum and Teaching, 12, 83-90. http://dx.doi.org/10.7459/ct/12.2.08

Hadzigeorgiou, Y. (1998). Science Activities for Preschool Children: Criteria of Their Selection. Unpublished Paper, Rhodes: University of the Aegean.

Hadzigeorgiou, Y. (1999). Problem Situations and Science Learning. School Science Review, 81, 43-48.

Hadzigeorgiou, Y. (2001). The Role of Wonder and "Romance” in Early Childhood Science Education. International Journal of Early Years Education, 9, 63-69.

Hadzigeorgiou, Y. (2002). A Study of the Development of the Concept of Mechanical Stability in Preschool Children. Research in Science Education, 32, 373-391. http://dx.doi.org/10.1023/A:1020801426075

Hadzigeorgiou, Y. (2014). On the Value of Wonder in Science Education. In K. Egan, A. Cant., \& G. Judson (Eds.), “Wonder-Full Education”: The Centrality of Wonder in Teaching and Learning across the Curriculum. New York and London: Routledge.

Hadzigeorgiou, Y. (2015). Young Children’s Ideas about Physical Science Concepts. In C. Trundle, \& M. Sackes (Eds.), Research in Early Childhood Science Education. Dordrecht and New York: Springer. (In Press)

Hadzigeorgiou, Y., \& Savage, M. (2001). A Study of the Effect of Sensorimotor Activities on the Understanding and Application of Two Fundamental Physics Ideas. Journal of Elementary Science Education, 31, 9-23. http://dx.doi.org/10.1007/BF03176216

Hadzigeorgiou, Y., Anastasiou, L., Prevezanou, B., \& Konsolas, M. (2009). A Study of the Effect of Preschool Children’s Participation in Sensorimotor Activities on Their Understanding of the Mechanical Equilibrium of a Balance Beam. Research in Science Education, 39, 39-55. http://dx.doi.org/10.1007/s11165-007-9073-6

Harlan, J. (1988). Science Experiences for the Early Childhood Years. Columbus, OH: Merrill.

Hammer, D. (1999). Physics for First Graders? Science Education, 83, 797-799. http://dx.doi.org/10.1002/(SICI)1098-237X(199911)83:6<797::AID-SCE9>3.0.CO;2-Y

Hirst, P. (1974). Liberal Education and the Nature of Knowledge. In P. Hirst (Ed.), Knowledge and the Curriculum: A Collection of Philosophical Papers. London: Routledge and Kegan Paul.

Hodson, D., \& Hodson, J. (1998). From Constructivism to Social Constructivism. A Vygotskian Perspective on Teaching and Learning Science. School Science Review, 79, 33-41.

Holt, B. (1993). Science with Young Children. Washington DC: National Association for the Education of Young Children.

Hong, S. Y., \& Diamond, K. (2012). Two Approaches to Teaching Young Children Science Concepts, Vocabulary, and Scientific Problem-Solving Skills. Early Childhood Research Quarterly, 27, 295-305.

http://dx.doi.org/10.1016/j.ecresq.2011.09.006

Howe, A. (1996). Development of Science Concepts within a Vygotskian Framework. Science Education, 80, 35-51. http://dx.doi.org/10.1002/(SICI)1098-237X(199601)80:1<35::AID-SCE3>3.0.CO;2-3

Kamii, C., \& DeVries, R. (1977). Piaget for Early Education. In M. Day, \& R. Parker (Eds.), Preschool in Action. Boston, MA: Allyn and Bacon.

Kamii, C., \& DeVries, R. (1993). Physical Knowledge in Preschool Education: Implications of Piaget's Theory. New York: Teachers College Press.

Kokoski, T., \& Downing-Leffler, N. (1995). Boosting Your Science and Maths Programs in Early Childhood Education. Young Children, 51, 35-39.

Landry, C., \& Foreman, G. (1999). Research on Early Science Education. In C. Seefeldt (Ed.), The Early Childhood Curriculum. New York: Teachers College Press.

Leuchter, M., Saalbach, H., \& Hardy, I. (2014). Designing Science Learning in the First Years of Schooling. International Journal of Science Education, 36, 1751-1771. http://dx.doi.org/10.1080/09500693.2013.878482

Levy, J. (1985). Right Brain, Left Brain: Fact and Fiction. Psychology Today, 19, 38-44.

Martin, B., \& Brouwer, W. (1991). The Sharing of Personal Science and the Narrative Element in Science Education. Science Education, 75, 707-722. http://dx.doi.org/10.1002/sce.3730750610

Marxen, C. (1995). Push, Pull, Toss, Tilt, Swing: Physics for Young Children. Young Children, 71, 212-216. 
Maxwell, S. (1995). Coming to Know about Children’s Learning. In S. Robson, \& S. Smedley (Eds.), Education in Early Childhood. London: David Fulton Publishers.

Navarra, J. (1955). The Development of Scientific Concepts in a Young Child. New York: Stratford Press.

Novak, J., \& Gowin, B. (1984). Learning How to Learn. Cambridge: Cambridge University Press. http://dx.doi.org/10.1017/CBO9781139173469

Nutbrown, C. (1994). Threads of Thinking: Young Children Learning and the Role of Early Education. London: Paul Chapman.

Ogden, C. (1967). Opposition. Bloomington, IN: Indiana University Press.

Peacock, G., Smith, R., \& Kirkby, D. (1994). Exploratory Materials and Energy. London: Hammersmith. (For National Curriculum Level 2-5)

Phenix, P. (1964). Realms of Meaning. New York: Norton.

Piaget, J. (1970). Genetic Epistemology. New York: Norton.

Piaget, J. (1976). Piaget’s Theory. In P. Neubauer (Ed.), The Process of Child Development. New York: Meridian.

Piaget, J. (1977). The Development of Thought. Equilibration of Cognitive Structures. Oxford: Basil Blackwell.

Popper, K. (1972). Objective Knowledge. Oxford: Clarendon Press.

Prawat, R. S. (1989). Promoting Access to Knowledge, Strategy and Disposition in Students: A Research Synthesis. Review of Educational Research, 59, 1-41. http://dx.doi.org/10.3102/00346543059001001

Reif, F., \& Larkin, J. (1991). Cognition in Scientific and Everyday Domains: Comparisons and Learning Implications. Journal of Research in Science Teaching, 28, 733-760. http://dx.doi.org/10.1002/tea.3660280904

Richards, K., Collins, M., \& Kincaid, D. (1987). An early Start to Science. London: McDonald.

Rogoff, B. (1990). Apprenticeship in Thinking: Cognitive Development in Social Context. New York: Oxford University Press.

Scheffler, I. (1991). In Praise of Cognitive Emotions. New York: Routledge.

Shepard, R. (1988). The Imagination of the Scientist. In K. Egan, \& D. Nadaner (Eds.), Imagination and Education. New York: Teachers College Press.

Sprung, S. (1996). Physics is Fun, Physics is Important and Physics Belongs in the Early Years. Young Children, 51, 29-33.

Sternberg, R., \& Berg, C. (Eds.) (1993). Intellectual Development. Cambridge: Cambridge University Press.

Stinner, A. (1995). Contextual Settings, Science Stories and Large Context Problems: Toward a More Humanistic Science Education. Science Education, 79, 555-581. http://dx.doi.org/10.1002/sce.3730790506

Stinner, A., \& Williams, H. (1993). Conceptual Change, History and Science Stories. Interchange, 24, 87-103. http://dx.doi.org/10.1007/BF01447342

Taylor, A. (1967). Imagination and the Growth of Science. New York: Schocken Books.

Taylor, B. (1993). Science Everywhere: Opportunities for Every Young Child. New York: Harcourt Brace and Jovanovich.

Trojack, D. (1979). Science with Children. New York: McGraw Hill.

Trundle, C., \& Sackes, M. (2015). Research in Early Childhood Science Education. Dordrecht and New York: Springer. (In Press)

Vygotsky, L. (1986). Thought and Language. Cambridge, MA: MIT Press.

Waite-Stupiansky, S. (1997). Building Understanding Together: A Constructivist Approach to Early Childhood Education. New York: Delmar.

Whitehead, A. (1929). The Aims of Education. New York: McMillan.

Woodard, C., \& Davitt, R. (1987). Physical Science in Early Childhood Education. Springfield, IL: Charles Thomas.

Womock, D. (1989). Developing Mathematical and Scientific Thinking in Young Children. London: Cassell. 
Scientific Research Publishing (SCIRP) is one of the largest Open Access journal publishers. It is currently publishing more than 200 open access, online, peer-reviewed journals covering a wide range of academic disciplines. SCIRP serves the worldwide academic communities and contributes to the progress and application of science with its publication.

Other selected journals from SCIRP are listed as below. Submit your manuscript to us via either submit@scirp.org or Online Submission Portal.
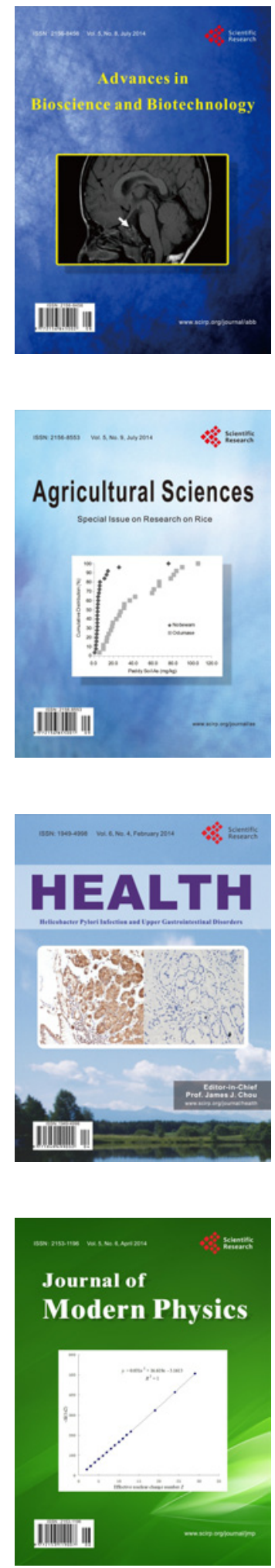
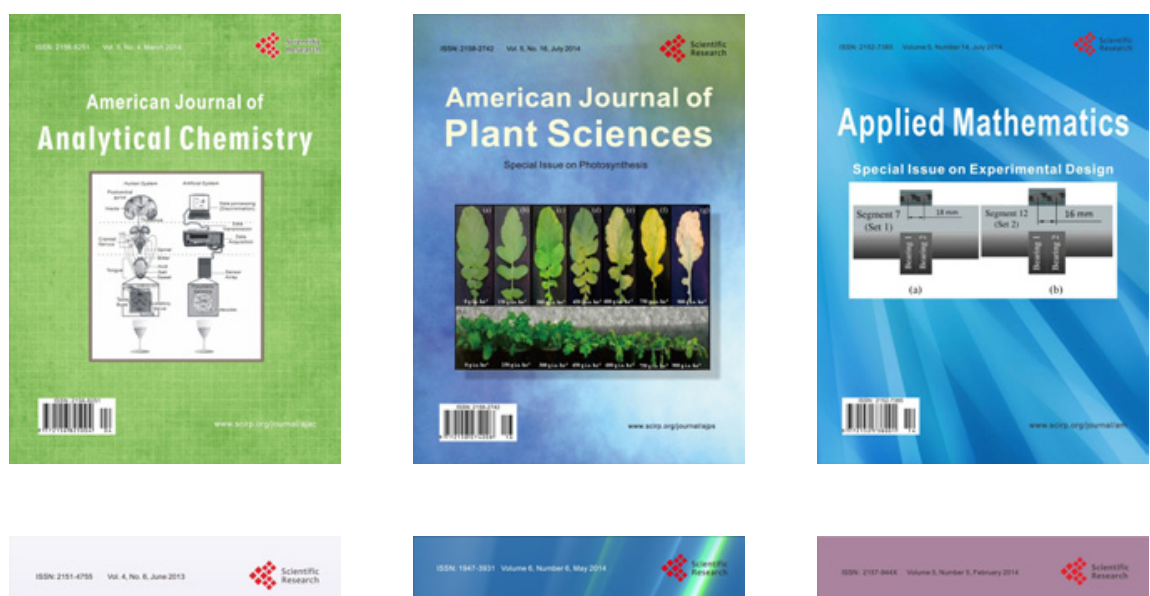

Creative Education
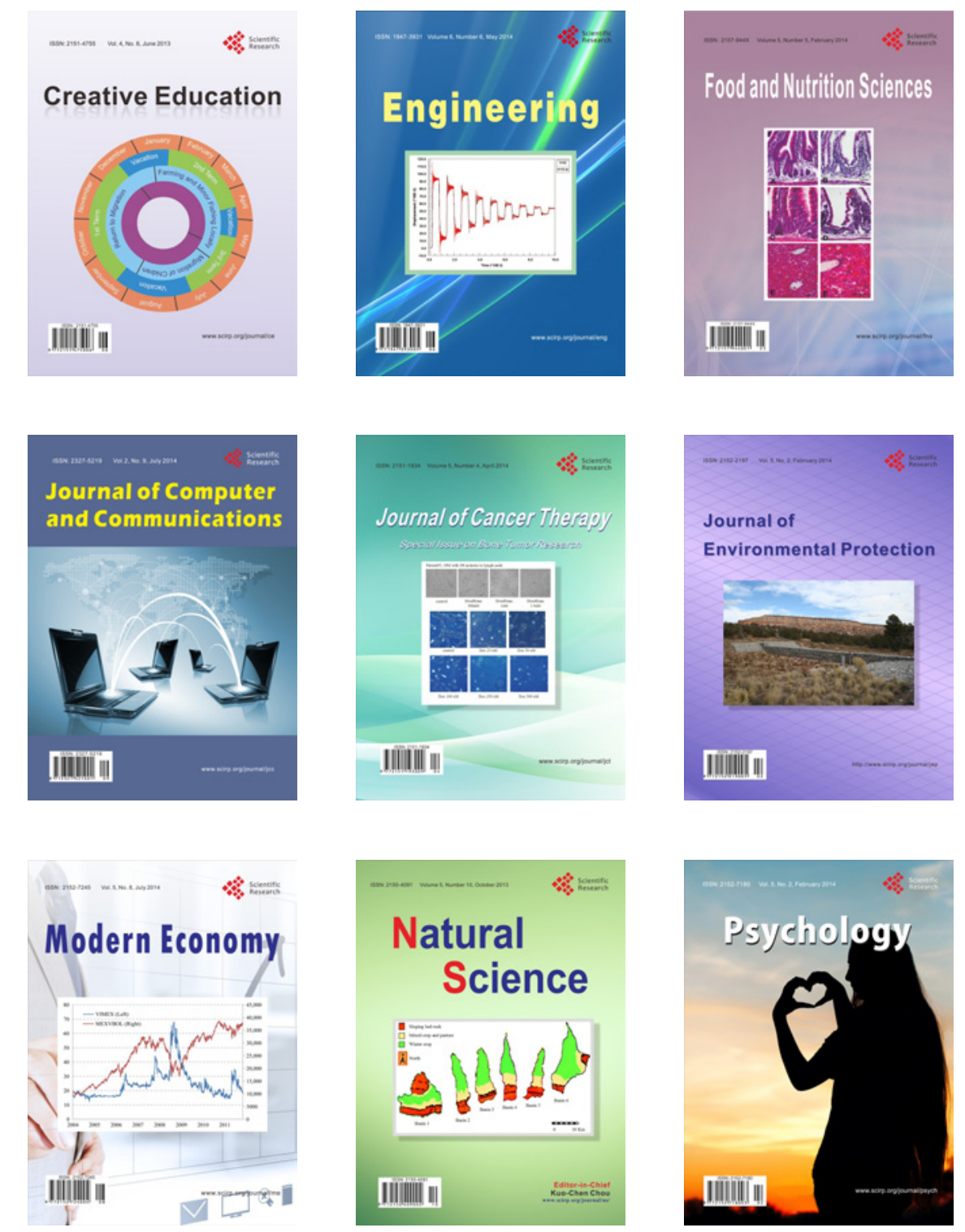